\title{
Seasonal variations in prolactin, growth hormone and thyroid hormones and the prolactin surge at ovulation do not affect litter size of ewes during pregnancy in the oestrous or the anoestrous season
}

\author{
N. Buys*, R. Peeters $\ddagger$, B. De Clerck $\ddagger$, J. Van Isterdael $\dagger$, E. R. Kühn* and \\ E. Decuypereł \\ * Laboratory of Comparative Endocrinology, Catholic University of Leuven, Naamsestraat 61 , \\ B-3000 Leuven, Belgium; $\nmid$ Zootechnical Centre, Catholic University of Leuven, Bijzondere weg 12, \\ B-3042 Lovenjoel, Belgium; and $\$$ Laboratory for Physiology of Domestic Animals, Catholic \\ University of Leuven, Kardinaal Mercierlaan 92, B-3030 Hervelee, Belgium
}

\begin{abstract}
Summary. Injection of bromocriptine from 5 days before until 5 days after mating clearly suppressed the periovulatory prolactin surge in ewes in the anoestrous and oestrous season but did not change the litter size significantly. Progesterone, GH, TSH or thyroid hormone concentrations were not influenced by the bromocriptine treatment. The progesterone concentrations were lower during the first weeks after mating in the anoestrous season compared to the oestrous season, while there was no difference between pregnant and non-pregnant ewes. During later gestation this seasonal difference was only observed in the non-pregnant ewes. At the same time there was a clear difference between pregnancy and non-pregnancy in both seasons. The prolactin, $\mathrm{GH}$ and thyroid hormone values also varied significantly during gestation. Since these patterns are identical in pregnant and non-pregnant ewes, the fluctuations are due to environmental factors and not to pregnancy or altered progesterone concentrations. In the anoestrous season prolactin, $\mathrm{GH}, \mathrm{T}_{4}$ and $\mathrm{T}_{3}$ levels were higher than in the breeding season, while $\mathrm{rT}_{3}$ showed the opposite pattern. The TSH concentration did not differ between the two seasons. These results suggest that seasonal variations in prolactin, $\mathrm{GH}$ and thyroid hormones or the periovulatory prolactin surge do not affect litter size of ewes during pregnancy in the oestrous or the anoestrous season.
\end{abstract}

Keywords: bromocriptine; litter size; pregnancy; season; ewe

\section{Introduction}

Blood concentrations of prolactin have a periovulatory peak value during the oestrous cycle of the ewe (McNeilly, 1980) but it is not clear whether this peak is necessary for a normal ovulation (Niswender, 1974; Rhind et al., 1985). Even so, the high prolactin concentrations during anoestrus are apparently not responsible for the inhibition of the ovarian activity during the anoestrous season (McNeilly, 1988). It was the purpose of this study to investigate the effect of suppressing the periovulatory prolactin peak on the fertilization rate and the litter size of the ewe. At the same time a comparison was made between the changes in prolactin, GH, progesterone, TSH and thyroid hormone concentrations in gestation in the oestrous and the anoestrous seasons. Although these hormones have extensively been studied during gestation in the oestrous season (Fylling, 1970; Fell et al., 1973; Hove \& Blom, 1976; Fraser \& McNeilly, 1982), nothing is known about their variation during gestation in the anoestrous season. 


\section{Materials and Methods}

All animals were produced at the Zootechnical Centre $\left(50^{\circ} 5^{\prime} \mathrm{N}\right.$ and $\left.4^{\circ} 5^{\prime} \mathrm{E}\right)$. In the oestrous (August) as well as in the anoestrous (April) season, 30 multiparous ewes of a crossbreed between Indigenous Milksheep and Suffolk sheep were treated with progestagen-impregnated pessaries and $1000 \mathrm{i} . \mathrm{u}$. PMSG (Intervet N.V., Brussels, Belgium) to synchronize the oestrous cycles. The oestrous season of these ewes started at the end of July, and so all the ewes treated in August had had at least one spontaneous cycle before the experiment was started. Comparison of reproduction in the oestrous and anoestrous seasons is not possible without induced ovulation and for methodological reasons of comparability PMSG-induced ovulation was applied in both seasons. In each season $1 \mathrm{mg} 2$-bromo- $\alpha$ ergocryptine (bromocriptine: Sandoz S.A., Basel, Switzerland) diluted in $50 \%$ ethanol $(1 \mathrm{ml})$ was injected (s.c.) twice daily (at 10:00 h and 22:00 h) into 15 ewes, from 5 days before until 5 days after mating. Blood samples were taken daily (at $18: 00 \mathrm{~h}$ ) from 2 days before until 5 days after mating and thereafter every 2 weeks during a period of 147 days. Plasma samples were stored at $-20^{\circ} \mathrm{C}$ until hormonal analysis was performed. Pregnancy or non-pregnancy was detected by the plasma progesterone concentrations on the 16th day of the oestrous cycle. Fertilization rate was determined as the number of ewes that lambed per 100 ewes mated and litter size as the number of lambs born per lambing ewe.

Several environmental factors were different for ewes mated in April compared with those mated in August: in the anoestrous season the mean temperature was higher $\left(14 \cdot 6^{\circ} \mathrm{C}\right.$ compared with $\left.8.7^{\circ} \mathrm{C}\right)$, the photoperiod was longer $(15 \mathrm{~h}$ $4 \mathrm{~min}$ compared with $9 \mathrm{~h} 45 \mathrm{~min} \mathrm{light/day)}$ and the available food during the gestational period was richer in proteins and total energy than in the oestrous season.

The immunoreagents of the sheep prolactin RIA and the sheep TSH RIA were provided by the National Institute of Diabetes, Digestive and Kidney Diseases (NIADDK, Bethesda, MD, USA). The purity of the antigens and the specificity of the antisera were guaranteed by the Institute. The intra- and inter-assay coefficients of variation were respectively $1 \%$ and $8 \%$ for the prolactin RIA and $3.3 \%$ and $10.7 \%$ for the TSH RIA. The GH concentrations were measured by a heterologous bovine RIA as described by Reynaert \& Franchimont (1974). Good parallelism has been obtained between the sheep plasma dilution curve and the bovine standard curve. Progesterone concentrations were measured by RIA following cyclohexane/ethylacetate extraction $(\mathrm{v} / \mathrm{v})$ and Dextrancoated charcoal separation of bound and unbound radioactivity (Verheyen et al., 1987). The thyroid hormone concentrations were evaluated by RIA using commercial kits: thyroxine $\left(\mathrm{T}_{4}\right.$, Abbott Diagnostics Division, Antwerp, Belgium), 3,3',5-triidothyronine ( $T_{3}$, antiserum from Mallinckrodt Diagnostica, Dietzenbach, FRG, and tracer from Amersham International, Bucks, UK) and 3,3',5'-triidothyronine ( $\mathrm{rT}_{3}$, Mallinckrodt Diagnostica). Results are expressed as the mean \pm s.e.m. To test whether the concentration of a hormone varied during the gestation period, we used the repeated measurements analysis of variance (General Linear Models procedure, SAS, 1985). The same test was used to determine the influence of the bromocriptine treatment and litter size on the different hormone concentrations. The statistical significance of differences between hormonal concentrations in pregnancy and nonpregnancy and in the oestrous and the anoestrous season were analysed by the Kruskal-Wallis test and the Mann-Whitney U test.

\section{Results}

In both seasons, treatment with bromocriptine from 5 days before until 5 days after mating clearly suppressed the peripheral prolactin concentrations during the whole period $(P<0.001)$. However, no significant difference in fertilization rate or in litter size could be observed (Table 1). Even so progesterone, growth hormone $(\mathrm{GH})$, thyrotrophin (TSH) and thyroid hormone concentrations were not influenced by the bromocriptine injections.

Table 1. Mean plasma prolactin concentration on the day of ovulation, fertilization rate and litter size in control and bromocriptine-treated ewes in the oestrous and anoestrous season

\begin{tabular}{|c|c|c|c|c|c|c|}
\hline \multirow[b]{2}{*}{ Season } & \multicolumn{2}{|c|}{ Prolactin conc. $(\mathrm{ng} / \mathrm{ml})$} & \multicolumn{2}{|c|}{ Fertilization rate } & \multicolumn{2}{|c|}{ Litter size } \\
\hline & Control & Bromocriptine & Control & Bromocriptine & Control & Bromocriptine \\
\hline Oestrous & $163 \cdot 5 \pm 43 \cdot 1(10)$ & $6 \cdot 7 \pm 1 \cdot 1(7)^{*}$ & 87 & 80 & $1.85 \pm 0.27$ & $2 \cdot 33 \pm 0.26$ \\
\hline Anoestrous & $543 \cdot 1 \pm 4 \cdot 8$ & $10 \cdot 0 \pm 3 \cdot 1(7)^{*}$ & 53 & 47 & $2 \cdot 00 \pm 0 \cdot 27$ & $1 \cdot 86 \pm 0 \cdot 26$ \\
\hline
\end{tabular}

Values are mean \pm s.e.m.

${ }^{*} P<0.001$ compared to control. 
As shown in Fig. 1(a) progesterone values increased during the first weeks after mating in all groups, corresponding to the luteal phase of the cycle. However, there was a clear difference between oestrous and anoestrous ewes, the latter having significantly much lower progesterone values, whether they were pregnant or not. During the following weeks, however, differences between pregnant and non-pregnant ewes became more obvious. While differences between seasonal progesterone concentrations remained unchanged in the non-pregnant ewes, differences in the high progesterone values were no longer detectable between pregnant ewes of both seasons during the last months of pregnancy, which is expressed in a significant season $\times$ diagnosis (pregnancy or non-pregnancy) interaction factor. In the oestrous season the progesterone concentrations did not seem to be influenced by the litter size of the ewe. Nevertheless, in the anoestrous season, ewes with more than 1 fetus showed a significantly higher and steeper pre-partum progesterone peak than did ewes carrying only 1 fetus.

Neither litter size, nor pregnancy itself influenced the prolactin, GH, TSH or thyroid hormone concentrations in a significant way (Figs $1 \mathrm{~b}-1 \mathrm{~g}$ ).

The ewes mated in the anoestrous season, whether they were pregnant or not, had significantly lower $\mathrm{rT}_{3}$ values $(P<0.00 \mathrm{I})$ than did the animals mated in the oestrous season. On the other hand, the prolactin, $\mathrm{GH}, \mathrm{T}_{4}$ and $\mathrm{T}_{3}$ concentrations were significantly $(P<0.001)$ higher in the anoestrous period than in the oestrous period. Season did not affect the TSH concentration.

\section{Discussion}

Injections of bromocriptine from 5 days before until 5 days after mating were very effective in reducing plasma concentrations of prolactin in sheep. In this study prolactin concentrations measured in bromocriptine-treated ewes were approximately $3 \%$ of those in control ewes $(14 \mathrm{ng} / \mathrm{ml}$ compared with $100-500 \mathrm{ng} / \mathrm{ml}$ ). Since injection of $1 \mathrm{mg}$ bromocriptine (s.c.) twice daily results in a continuous suppression of the prolactin secretion (Land et al., 1980), it can be concluded that the prolactin concentration was reduced during the whole treatment period, although there did not seem to be any effect on the ovulation rate. Neither the luteal-phase plasma progesterone values, nor the litter sizes, nor the fertilization rates were different between bromocriptine-treated and control animals. This contradicts the findings by Rhind et al. (1985) when they state that the prolactin peak reached during the first hours after oestrus is necessary for a normal ovulation rate but supports the findings by Niswender (1974) in so far that in the cyclic ewe ovulation rate and luteal function are not affected by suppression of prolactin levels with bromocriptine. Whether the lack of any suppressive effect of prolactin on PMSG-induced ovulation can be applied to a naturally occurring ovulation is not known. However, since no influence of bromocriptine on gonadotrophin secretion in sheep could be observed in the oestrous season (Niswender, 1974) or in the anoestrous period (Land et al., 1980), it is very likely that our conclusions can also be extrapolated to a naturally occurring ovulation. Progesterone concentration changes during gestation in the oestrous and the anoestrous season were similar to reports in the literature (Bassett et al., 1969; Fylling, 1970). The progesterone concentrations in the first weeks of pregnancy during the anoestrous season are lower than respective values during the oestrous season, which suggests a different reproductive capacity of the corpora lutea in the two seasons. This result may reflect a higher ovulation rate after synchronization of oestrus in the normal oestrous season compared to the anoestrous season (Cahill, 1981). This was also observed in the non-pregnant ewes during the whole experimental period, even long after luteal regression. A higher progesterone metabolism or breakdown during the anoestrous season cannot be excluded as an additional factor explaining lower progesterone concentrations during the oestrous season. Although prolactin concentrations did not vary during the first 142 days of gestation, a peak value $(\sim 300 \mathrm{ng} / \mathrm{ml})$ on the day of parturition (N. Buys \& R. Peeters, unpublished data) occurred, which confirms the results of Fell 

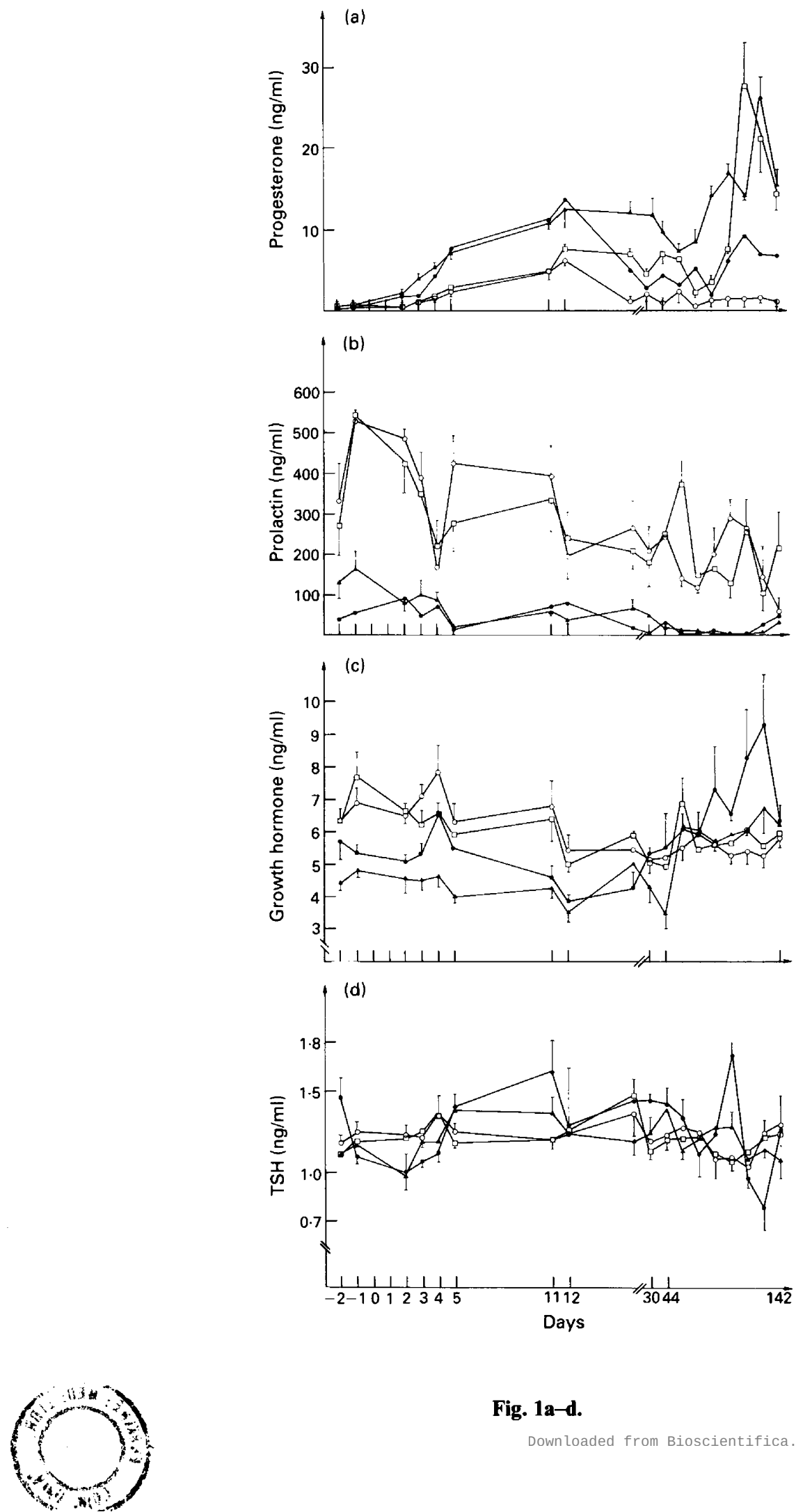

Fig. 1a-d. 

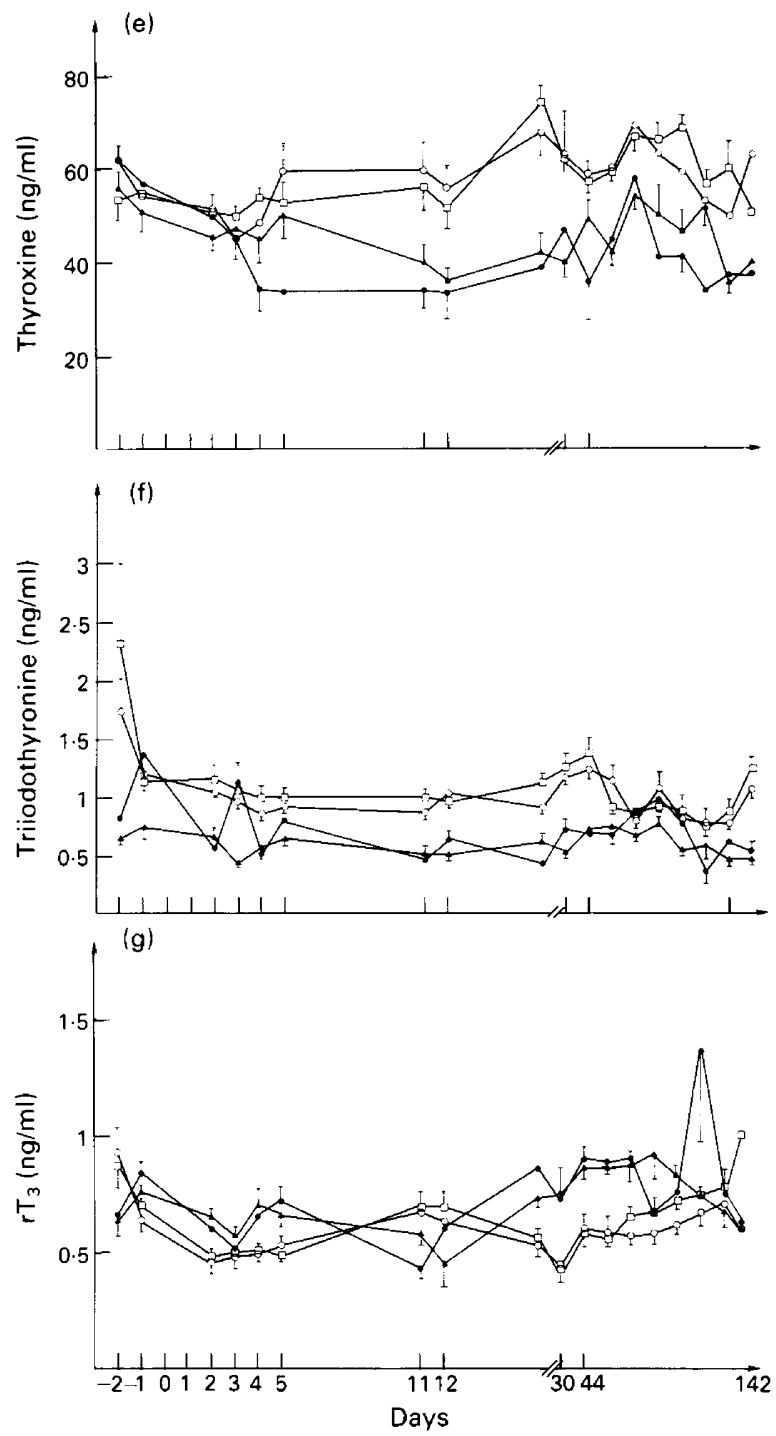

Fig. 1e-g.

Fig. 1. Plasma progesterone (a), prolactin (b), GH (c), TSH (d), thyroxine (e), triiodothyronine (f) and $\mathrm{rT}_{3}(\mathrm{~g})$ concentrations in pregnant and non-pregnant ewes in the oestrous and the anoestrous season. Day 0 is day of mating. Values are mean \pm s.e.m. $\square$, Anoestrous, pregnant $(\mathrm{N}=15) ; \mathrm{O}$, anoestrous, non-pregnant $(\mathrm{N}=13) ; \boldsymbol{\Delta}$, oestrous, pregnant $(\mathrm{N}=17) ;$ oestrous, non-pregnant $(\mathrm{N}=2)$.

et al. (1973). The well known seasonal pattern of prolactin (Webster \& Haresign, 1983) was confirmed in this study since prolactin concentrations were significantly $(P<0.001)$ higher during the anoestrous season compared to the oestrous season. This circannual rhythm of prolactin is mainly regulated by changes in photoperiod and would not be due to altered TRH levels since the rhythm is still obvious in TRH-immunoneutralized ewes (Fraser \& McNeilly, 1982). Moreover, we could not observe any seasonal influence on plasma TSH concentrations. Although sheep show sge 
reproduction, the high prolactin concentrations are a symptom of seasonal anoestrus rather than a proximate cause (Jackson \& Davis, 1979).

In both seasons there was no difference in the $\mathrm{GH}$ concentrations between pregnant and nonpregnant ewes. The significant effect of season on the $\mathrm{GH}$ values is probably due to the lower $\mathrm{GH}$ concentrations during the first 15 days after mating in the oestrous season. This could be caused by a different food supply between April and August (Forbes et al., 1979).

The significant differences between both seasons for the thyroid hormone concentrations agree with the findings of Fraser \& McNeilly (1982) and indicate that the influence of several environmental factors, such as temperature (Johnson, 1986), photoperiod (Lincoln et al., 1980) and feeding level (Fitzgerald et al., 1982), could be responsible for the circannual rhythm of thyroid hormones in sheep. Apparently this circannual rhythmicity was not disturbed by pregnancy since no differences were observed between pregnant and non-pregnant ewes in either season. The relative importance of the different environmental factors could not be distinguished. Although we would expect higher thyroxine and triiodothyronine concentrations during the winter months (Johnson, 1986), the opposite pattern was observed. This could be due to a reduced metabolic clearance rate of thyroid hormones during the summer. On the other hand, the increased heat loss caused by shearing could result in higher thyroid hormone concentrations. The fact that triiodothyronine and thyroxine on the one hand, and $\mathrm{rT}_{3}$ on the other showed opposite changes as a function of the season, while TSH remained unchanged, indicates that the seasonal factors act proximately on the peripheral metabolism of thyroxine rather than on the central axis.

We thank Mr W. Van Ham, Ms F. Voets, Ms L. Noterdaeme and Ms G. Nackaerts for technical assistance; and Ir O. Siau for statistical analysis. This research was supported by I.W.O.N.L. (Instituut ter aanmoediging van het Wetenschappelijk Onderzoek in Nijverheid en Landbouw).

\section{References}

Bassett, J.M., Oxborrow, T.J., Smith, I.D. \& Thorburn, G.D. (1969) The concentration of progesterone in the peripheral plasma of the pregnant ewe. J. Endocr. 109, 307-312.

Cahill, L.P. (1981) Folliculogenesis in the sheep as influenced by breed, season and oestrous cycle. $J$. Reprod. Fert., Suppl. 30, 135-142.

Fell, L.R., Findley, J.K., Cumming, I.A. \& Goding, J.R. (1973) Effect of synthetic TRF on prolactin release in the sheep. Endocrinology 93, 487-491.

Fitzgerald, B.F., Michel, F. \& Butler, W.R. (1982) Growth and sexual maturation in ewes. The role of photoperiod, diet and temperature on growth rate and the control of prolactin, thyroxine and luteinizing hormone secretion. J. Anim. Sci. 55, 1431-1440.

Forbes, J.M., Driver, P.M., Brown, W.B., Scanes, C.G. \& Hart, I.C. (1979) The effect of daylength on the growth of lambs. 2. Blood concentrations of growth hormone, prolactin, insulin and thyroxin, and the effect of feeding. Anim. Prod. 29, 43-51.

Fraser, H.M. \& McNeilly, A.S. (1982) Effect of chronic immunoneutralization of thyrotropin releasing hormone on the hypothalamic pituitary thyroid axis, prolactin and reproductive function in the ewe. Endocrinology 111, 1964-1973.

Fylling, P. (1970) The effect of pregnancy, ovariectomy and parturition on plasma progesterone levels in sheep. Acta endocr., Copenh. 65, 273-283.

Hove, R. \& Blom, A.K. (1976) Plasma insulin and growth hormone concentrations in pregnant sheep. I. Diurnal variations in mid- and late pregnancy. Acta endocr., Copenh. 82, 544-552.
Jackson, G.L. \& Davis, S.L. (1979) Comparison of luteinizing hormone and prolactin levels in cycling and anestrous ewes. Neuroendocrinology 28, 256-263.

Johnson, A.L. (1986) Serum concentrations of prolactin, thyroxine and triiodothyronine relative to season and estrous cycle in the mare. J. Anim. Sci. 62, 1012-1020.

Land, R.B., Carr, W.R., McNeilly, A.S. \& Preece, R.D. (1980) Plasma FSH, LH, the positive feedback of oestrogen, ovulation and luteal function in the ewe given bromocriptine to suppress prolactin during seasonal anoestrus. J. Reprod. Fert. 59, 73-78.

Lincoln, G.A., Klandorf, H. \& Anderson, N. (1980) Photoperiodic control of thyroid function and wool and horn growth in rams and the effect of cranial sympathectomy. Endocrinology 107, 1543-1548.

McNeilly, A.S. (1980) Prolactin and the control of gonadotrophin secretion in the female. $J$. Reprod. Fert. 58, $537-549$.

McNeilly, A.S. (1988) Interactions between prolactin and gonadotropin secretion. In Progress in Endocrinology, pp. 1399-1401. Eds H. Imura, K. Shizume \& S. Yoshida. Elsevier Science Publishers B.V., Amsterdam.

Niswender, G.D. (1974) Influence of 2-Br- $\alpha$-ergocryptine on serum levels of prolactin during the estrous cycle of the ewe. Endocrinology 94, 612-615.

Reynaert, R. \& Franchimont, P. (1974) Radioimmunoassay of bovine growth hormone. Annls Endocrinol. 35, 139-148.

Rhind, S.M., Leslie, I.D., Gunn, R.G. \& Doney, J.M. (1985) Plasma FSH, LH, prolactin and progesterone 
profiles of Cheviot ewes with different levels of intake before and after mating, and associated effects on reproductive performance. Anim. Reprod. Sci. 8, 301-313.

SAS (1985) Statistical Analysis System: SAS users guide Statistics (Version 5 edition). Cary, NC.

Verheyen, G., Decuypere, E., Chiasson, R.B., Vervloesem, J., Kühn, E.R. \& Michels, H. (1987) Effect of exogen- ous LH on plasma concentrations of progesterone and oestradiol in relation to cessation of egg laying induced by different moulting methods. $J$. Reprod. Fert. 81, 13-21.

Webster, G.M. \& Haresign, W. (1983) Seasonal changes in prolactin concentrations in ewes of two breeds. $J$. Reprod. Fert. 67, 465-471.

Received 16 October 1989 